\title{
COOPERAÇÃO JURISDICIONAL TRANSFRONTEIRIÇA: Uma análise comparativa entre o Mercosul e a União Européia
}

\author{
Caroline Padilha da Silva ${ }^{1}$ \\ Denize Reginato Mafaldo ${ }^{2}$ \\ Luiza Scopel Hoffmann ${ }^{3}$
}

RESUMO:

Com a globalização e a reavaliação de políticas, resultado da nova realidade políticoeconômica, surgiu a necessidade de adaptação dos mecanismos de integração existentes. Surge, assim, um Direito Comunitário que regula as relações entre as nações.

$\mathrm{Na}$ Comunidade Européia o interesse prevalente é o comunitário, no qual o coletivo se sobrepõe ao individual e até mesmo ao dos Estados-membros. Essa prevalência é reconhecida como o poder de supranacionalidade; primazia do Direito Comunitário que concretiza o mecanismo da Cooperação Jurisdicional no âmbito do bloco.

No Mercosul, caracterizado pela intergovernamentabilidade, cada Estado-membro possui interesses próprios, ou seja, a vontade predominante é a individual, não havendo pensamento de interesse comum e não existindo supremacia das regras internacionais frente aos ordenamentos nacionais. Cada país preserva sua autonomia ao extremo.

Diante disso, percebe-se que o mecanismo da Cooperação Jurisdicional Transfronteiriça é ineficaz para um bloco econômico como o Mercosul, o qual apresenta dificuldades e disparidades que não serão suprimidas pela simples adoção de um modelo cooperativo supranacional como o europeu, visto que a América Latina segue os moldes do direito internacional clássico, ou seja, centrado em uma consensualidade, ficando a cargo de cada Estado dirimir seus entraves.

Palavras-chaves: Cooperação Jurisdicional (judicial), União Européia, Mercosul.

\section{JURISDICTIONAL COOPERATION: a comparative analysis between Mercosur and the European Union}

\begin{abstract}
:
With globalization and the reassessment of politics, result of the new political and economic reality, there was a need to adapt the mechanisms for collaboration. Therefore, a legal system that regulates relations between the nations arose.

In European Union prevails the communitarian interests, in which the collective overlaps the individual and even the Member States. This prevalence is recognized as the power of supranationality; rule of law which embodies the mechanism of jurisdictional cooperation.

In Mercosur, an intergovernamental organization, each Member State has its own interests, which means the predominant will is the individual one, with no thought of common interest and no supremacy of international rules ahead to national jurisdictions. Each country retains its autonomy to the extreme.

Therefore, it is clear that the mechanism of jurisdictional cooperation is inefficient for an economic bloc such as Mercosur, which presents difficulties and differences that will not disappear for the simple adaptation of a supranational model as the one of the European Community, since Latin America follows the classic mould of international law, which is centered in a consensualidade, leaving it to each state to address their barriers.

\footnotetext{
1 Acadêmica do Curso de Direito da Universidade Federal de Santa Maria, carolipa04@ yahoo.com.br

2 Acadêmica do Curso de Direito da Universidade Federal de Santa Maria, denizemafaldo@ yahoo.com.br

${ }^{3}$ Acadêmica do Curso de Direito da Universidade Federal de Santa Maria, luizadireito@yahoo.com.br
} 
Key-words: Jurisdictional Cooperation - Mercosur - European Union

\section{INTRODUÇÃO}

O presente estudo traz como plano central de análise a Cooperação Jurisdicional Transfronteiriça, a qual funciona como instrumento processual de integração que concretiza direitos em um espaço além das fronteiras de um Estado.

O desenvolvimento desse artigo será estabelecido a partir do ordenamento jurídico de dois blocos econômicos: a União Européia e o Mercosul. Num primeiro momento, far-se-á a análise da Comunidade Européia, destacando a primazia dada ao direito comunitário, que viabiliza, concretiza o mecanismo da cooperação jurisdicional. Paralelamente, mostrar-se-á como esse instrumento é aplicado no âmbito mercosulino, destacando seus principais aspectos.

Feito isso, objetiva-se demonstrar a ineficácia da Cooperação Jurisdicional Transfronteiriça no Mercado Comum do Sul. A problemática será estabelecida basicamente demonstrando-se a dificuldade de se implementar um órgão supranacional vinculante, que estabeleça de forma direta e objetiva a harmonização jurisprudencial dos países pertencentes ao bloco mercosulino.

Destacam-se fatores que influenciam essa situação: a disparidade sóciopolítico-econômica dos Estados que compõem os blocos, bem como a dificuldade de implementar a Cooperação Jurisdicional Transfronteiriça no Mercosul em razão da inexistência de um Direito Comunitário superior à supremacia destes Estados-membros.

\section{SISTEMAS DE INTEGRAÇÃO COMUNITÁRIA}

A globalização impôs aos Estados uma reavaliação de suas políticas a fim de facilitar sua integração. Dessa forma, surgiu a necessidade de adaptação dos mecanismos de integração. Outrossim, diante da nova realidade político-econômica emergente na esfera mundial, fez-se importante o surgimento de um direito comunitário que bem regulasse as relações entre as nações.

Ressalve-se, entretanto, que os processos de integração exigem uma adaptação do ordenamento jurídico dos Estados que se agrupam para constituir uma ordem comum. Sobreleva notar, pois, nesse contexto, o sistema de integração presente na ISSN 1981-3694

(C) 2008. Departamento de Direito da UFSM. Todos os direitos reservados. 
comunidade européia, do qual resultou o que é hoje conhecido como União Européia. De maneira diversa, em um modelo bem menos rígido, encontra-se o Mercosul (Mercado Comum do Sul), o qual, muito embora almeje uma integração, aproveita de forma singela os postulados do direito comunitário e do próprio Direito Internacional Público ${ }^{4}$.

\subsection{União Européia}

\subsubsection{Considerações Gerais}

O mundo europeu no período pós-guerra encontrou a necessidade de reconstruir suas nações e, de certa forma, reabilitar-se na esfera mundial. Outrossim, estruturou-se na Comunidade Européia do Carvão e do Aço (CECA) e, em continuidade a esse mecanismo, surgiu a União Européia, criada em 2002, a partir do Tratado de Maastricht.

$\mathrm{Na}$ Europa, o sistema de integração é único, atingindo, em seu avanço histórico, o apogeu no que diz respeito à cooperação entre Estados. O sistema europeu consiste no paradigma mais organizado e perfeito no que tange à integração. Em um mesmo bloco, conseguiu-se consolidar um espaço sem fronteiras, onde se preza pela circulação livre das pessoas pelos países que dela fazem parte. Constitui-se, pois, o verdadeiro mercado comum.

Nesse diapasão, a União Européia conta com um sistema judiciário ímpar, consolidando o Direito Comunitário da melhor maneira possível. Instituiu-se um mecanismo que consubstanciou o direito internacional e as suas reflexões sóciopolíticas.

Com o constante aperfeiçoamento da estrutura judicial da União Européia, chegou-se, hoje, a um instrumento de integração próprio e almejado pelos países do globo. Sob esse prisma, destaca-se o Tribunal de Justiça das Comunidades Européias (TJCE), órgão constituído pelo atual artigo 234 (ex-artigo 177) do Tratado da Comunidade Européia, o qual conta com mecanismos que permitem estabelecer a supremacia do Direito Comunitário, fazendo, para tanto, o uso do reenvio prejudicial e das ações próprias previstas na legislação comum. $\mathrm{O}$ mencionado dispositivo estabelece:

\footnotetext{
${ }^{4}$ SEITENFUS, Ricardo; VENTURA, Deisy. Direito Internacional Público. Porto Alegre: Livraria do Advogado, 2006, p.204.
} ISSN 1981-3694

(C) 2008. Departamento de Direito da UFSM. Todos os direitos reservados. 
O Tribunal de Justiça é competente para decidir, a título prejudicial:

a) Sobre a interpretação do presente Tratado;

b) Sobre a validade e a interpretação dos atos adotados pelas Instituições da Comunidade e pelo BCE;

c) Sobre a interpretação dos estatutos dos organismos criados por ato do Conselho, desde que estes estatutos o prevejam.

Coerente é a afirmação de Ramón Lisboa, pela qual “(...) a primeira característica que se destaca do TJCE é seu caráter supranacional, o que confere às suas decisões um caráter impositivo, dado que cada Estado-membro abdicou parcela de sua soberania com o fim de submeter-se às decisões desse colegiado que está acima das nações". 5 Segue o desenvolvimento de seu trabalho: "Além do caráter impositivo de suas decisões, outro elemento distintivo repousa na sua condição de obrigatoriedade, pois, diferentemente de outras jurisdições com caráter internacional, o TJCE avocou competência dos Estados-membros em determinadas matérias, tornando-se instância obrigatória".

Desse modo, importante consignar que, em razão da amplitude territorial do espaço europeu e da vasta discórdia geradora de desídias, fez-se essencial a criação de um mecanismo hábil e capaz de permitir a aplicabilidade do direito comunitário pelos juízes nacionais e, ao mesmo tempo, permitir a harmonia interpretativa e a uniformização da jurisprudência. Trata-se, pois, do mecanismo do reenvio prejudicial.

\subsubsection{Reenvio Prejudicial}

A figura do reenvio prejudicial é um importante mecanismo presente no sistema europeu.

Segundo Jânia Maria Lopes Saldanha, o reenvio prejudicial “(...) é uma figura de direito processual comunitário responsável pelo intercâmbio cooperativo existente entre as jurisdições nacionais e o Tribunal de Justiça"6 . É tido por instrumento porque é ele que faz chegar ao Tribunal de Justiça a questão prejudicial de Direito Comunitário nascida no curso do processo. O reenvio prejudicial, portanto, surge dentro do processo e tem o condão de apreciar matéria de interpretação e/ou validade de uma norma comunitária e não reapreciar atos já decididos pelo juiz nacional. Este tem o dever de atentar para o resultado dado pelo Tribunal de Justiça ${ }^{7}$.

\footnotetext{
${ }^{5}$ LISBOA, Ramón. Justiça Transfronteiriça: uma análise comparativa das estruturas judiciais e mecanismos de cooperação jurisdicional em matéria civil e comercial entre o Mercosul e a União Européia \{Tese\}. Santa Maria: MILA, 2006.

${ }^{6}$ SALDANHA, Jânia Maria Lopes. Cooperação Jurisdicional - Reenvio Prejudicial: um mecanismo de direito processual a serviço do direito comunitário: perspectivas para a sua adoção no Mercosul. Porto Alegre: Livraria do Advogado, 2001, p.29

${ }^{7}$ Idem, p.33.
}

ISSN 1981-3694

(C) 2008. Departamento de Direito da UFSM. Todos os direitos reservados. 
$\mathrm{Na}$ doutrina, há uma grande escassez quanto ao procedimento que se deve seguir, pois não existem regras rígidas sobre o rito do reenvio prejudicial. Isso demonstra a preocupação muito maior em dar uma resposta aos Estados-membros e suas jurisdições do que propriamente a forma adotada. Assim, afirma-se não ter um momento certo para que seja suscitado. Perante as jurisdições nacionais, o procedimento adotado poderá ser feito conforme o modelo, o qual não pode ser encarado como um modelo absoluto:

a) $\mathrm{O}$ juiz nacional resolve submeter o TJCE à apreciação sobre a interpretação ou validade das normas comunitárias, invocadas pelas partes no processo principal (artigo 234 do Tratado da Comunidade Européia);

b) Os juízes remetem o pedido de apreciação através de petição que conterá o relatório sobre os fatos abordados nos processo principal, fundamentos jurídicos e as questões prejudiciais de Direito Comunitário para apreciação do TJCE;

c) O TJCE recebe o reenvio prejudicial e faz sua análise. Este órgão, via de regra, é obrigado a responder à jurisdição nacional quando provocado, segundo o artigo 234 do Tratado da Comunidade Européia. Não tem ele a possibilidade de questionar sobre a análise ou não da suscitação. Por conseqüência, o juiz do processo principal deve basear-se nessa decisão, ou seja, atrelar-se à manifestação dada pelo TJCE.

Como é cediço, o instituto do reenvio prejudicial funciona como um conector, o qual interliga o Tribunal de Justiça aos juízes nacionais, com o intuito de tornar efetiva a aplicabilidade do Direito Comunitário. Resta evidente, portanto, o caráter consultivo desse instituto, do qual as decisões não cabem recurso. Quando suscitado pelo país, o reenvio prejudicial tem o condão de sobrestar o processo principal até que seja proferida a decisão definitiva do juízo consulente. Ninguém pode obrigar o juiz a suscitar o TJCE, já que cabe a ele a decisão acerca da possibilidade de proceder ao envio ou não da questão prejudicial.

Essa figura processual, portanto, é tida como responsável pela evolução e uniformização da matéria de Direito Comunitário na Europa.

Qualquer órgão nacional que tenha função e lugar no sistema de proteção jurisdicional do Estado a que pertença está autorizado a proceder o reenvio prejudicial. Esse é entendimento liberal do TJCE, independente de sua denominação. 
A amplitude do mecanismo é tanta que não delimita a matéria sobre a qual versa a questão principal, excluindo-se, porém, da possibilidade de interpretação, acordos e convenções firmados entre os Estados-membros. De tal forma, o instituto apresenta princípios peculiares que funcionam como pilares da ordem comunitária. São eles: o princípio da aplicabilidade imediata e o princípio da primazia do direito comunitário.

O primeiro deles é o da aplicabilidade imediata, o qual compreende a internacionalização imediata e automática das normas de caráter comunitário. Assim sendo, as decisões tomadas pelo Tribunal de Justiça não são passíveis de anulabilidade em razão de uma suposta incompatibilidade com o ordenamento pátrio. As regras comunitárias incorporam-se ao ordenamento jurídico nacional imediatamente, dispensando-se, assim, qualquer forma especial de internacionalização. Percebe-se que este princípio consagra de maneira eficaz o integracionalismo almejado pela comunidade européia

Por sua vez, o princípio da primazia do direito comunitário faz nascer a idéia de que as decisões do Tribunal de Justiça, quando suscitado para se manifestar acerca do reenvio de questão prejudicial, incorporam-se ao ordenamento jurídico nacional, muito embora não se confunda com a legislação vigente. As regras de direito comunitário, em que pese a possibilidade de contrariar o ordenamento do país, consolidam o posicionamento da supremacia do direito comunitário em detrimento da soberania dos Estados.

Em diversas decisões históricas, como, por exemplo, o conhecido caso Costa e $\mathrm{Enel}^{8}$, o Tribunal de Justiça da Comunidade Européia foi chamado a se manifestar acerca da supremacia do Direito Comunitário, sendo que, em todos os posicionamentos que prolatou, consolidou o alcance e a eficácia das decisões, tornando-se, assim, base legal e suprema para o Direito Comunitário.

\subsubsection{Cooperação Jurisdicional Transfronteiriça na União Européia}

A cooperação jurisdicional, além de implicar em reflexos no âmbito do espaço comunitário, apresenta também conseqüências no Direito Internacional, da maneira mais vasta e abrangente possível. O reconhecimento de um direito consubstanciado num

${ }^{8}$ Sobre o tema, http://www.cebri.org.br/pdf/272_PDF.pdf

ISSN 1981-3694

(C) 2008. Departamento de Direito da UFSM. Todos os direitos reservados. 
Estado em outro é fixado pelo mecanismo da cooperação jurisdicional para efetivação do ato judicial estrangeiro.

\section{Como bem lembra LISBOA:}

Ocorre que, a cooperação interjurisdicional envolve múltiplas questões afetas substancialmente ao exercício da soberania do Estado, pois ao aceitar o cumprimento de uma sentença proferida em outro Estado, automaticamente abdica de sua jurisdição (competência) para resolução do mesmo, e com isso, afasta a aplicação de seu ordenamento jurídico ao caso, efetuando tãosomente o reconhecimento e a execução da norma concreta já transformada em sentença pelo Estado requerente (LISBOA, 2006, p.45).

Continua o autor:

Entretanto, em um espaço autenticamente comunitário, em que as barreiras fronteiriças sedem [sic] lugar para integração supranacional entre os Estadosmembros, os mecanismos de cooperação jurisdicional também recebem tratamento diferenciado no sentido de privilegiar as sentenças proferidas intrabloco, diminuindo-se as exigências e buscando acelerar a sua efetivação, conforme se observa na trajetória de desenvolvimento das instituições européias (LISBOA, 2006, p.47).

Com o mecanismo de integração que a União Européia dispõe, a Convenção de Bruxelas buscou uma solução uniforme para evitar as contradições existentes nas esferas da competência das nações que dela fazem parte. Essa convenção, além de positivar normas sobre o reconhecimento e execução da sentença estrangeira, consubstanciou a definição de competência internacional entre os países membros.

Ademais, a União Européia conta com um instrumento importante para a circulação das sentenças proferidas por seus membros. O chamado título executivo europeu é meio utilizado para garantir a livre circulação de sentenças proferidas no espaço integrado. Assim, de posse desse instrumento, basta ao sujeito ativo da relação jurídico-processual solicitar seu cumprimento por meio do exequatur. ${ }^{9}$.

De maneira igual, a Constituição Européia reforça a idéia de integralização, positivando o postulado de que facilitará o acesso à justiça, através do reconhecimento mútuo das decisões judiciais e extrajudiciais em matéria civil.

Percebe-se que, como lembra LISBOA:

A cooperação jurisdicional na União Européia pode contar com um sistema simplificado e uniforme de regras para o reconhecimento de sentenças estrangeiras, além de normas com caráter comunitário estabelecendo competência internacional, e como corolário dessa superestrutura normativoinstitucional voltada para efetividade dos direitos no plano transnacional,

\footnotetext{
${ }^{9} \mathrm{O}$ exequatur nada mais é que uma ordem para cumprimento da decisão. Sobre o assunto, POZZATTI JR., Ademar. Mecanismos de Cooperação Jurisdicional e de Harmonização da Aplicação do Direito Regional: assimetrias entre o Mercosul e a União Européia. \{Monografia\}. Santa Maria: 2007.
} 
ainda existe o título executivo comum a todo Espaço Europeu (LISBOA, 2006, p.72).

Pelo que foi explanado, percebe-se como é bem estruturado e organizado o mecanismo da cooperação jurisdicional no bloco europeu.

\subsubsection{Tribunal de Justiça como instrumento realizador da Cooperação Judicial}

O Tribunal de Justiça das Comunidades Européias é o instrumento processual a serviço da cooperação jurisdicional naquele bloco; órgão com competência definida à apreciação da matéria comunitária. Age no contencioso comunitário e também em conjunto com as jurisdições nacionais, respondendo questões que lhes sejam formuladas. Portanto, sempre que algum Estado-membro necessitar de auxílio para interpretação de alguma norma de Direito Comunitário, pode socorrer-se ao Tribunal de Justiça para que ele se pronuncie a respeito.

O Tribunal tem o condão de uniformizar a ordem jurídica comunitária, seja quando age como órgão de última instância ou quando decide questões prejudiciais, ao interpretar o Direito Comunitário e atuar como cooperador judicial.

Tem como objetivos: I) assegurar o controle jurídico; II) desenvolver as potencialidades do sistema normativo comunitário e III) suprir as lacunas dos tratados constitutivos, com recurso a variados métodos de interpretação.

Se não tivesse o Tribunal de Justiça regulamentando e uniformizando a jurisprudência, de que forma os juízes nacionais poderiam ser amparados quando tivessem dúvidas sobre interpretação ou validade das normas comuns?

Como se percebe, a instituição de um Tribunal é a via centralizadora das decisões, capaz de estabelecer uma jurisprudência una aplicável a todo o contexto do bloco. A supranacionalidade desse órgão faz com que a integração almejada seja efetivamente configurada, circunstância que leva à formação de um ordenamento comunitário sui generis.

\subsection{Mercosul}

O Tratado de Assunção, de 26 de março do ano de 1991, foi o ato que deu origem ao Mercado Comum do Sul - o Mercosul. Por meio desse acordo, instituiu-se um mercado comum e progressivo entre Argentina, Brasil, Paraguai e Uruguai. A partir 
de sua criação, o Mercosul constitui uma organização que visa satisfazer interesses de seus Estados-membros, especialmente de ordem econômica.

O Mercosul é um órgão dotado de personalidade jurídica de direito internacional público, pelo que restou estabelecido no Protocolo de Ouro Preto, positivado na data de 17 de dezembro de 1994.

Muito embora o Mercosul tenha por objetivo estabelecer um mecanismo de cooperação jurisdicional, percebe-se que tal organização é dotada de fragilidade, uma vez que, após diversas tentativas de integração, não conseguiu estabelecer uma comunidade como a União Européia. Com a instituição do Mercosul, cria-se uma estrutura judicial com profundas assimetrias, onde não há, por exemplo, um Tribunal supracional, tampouco um título executivo mercosulino. Todavia, é incontestável que se tenta estabelecer a atuação de um sistema de solução de controvérsias, com a aplicação de regras próprias e de mecanismos de cooperação para as decisões proferidas pelos Estados-membros.

Infelizmente, não se vislumbra no âmbito desse mercado comum uma corte que tenha legitimidade para proferir decisões capazes de estabelecer uma legislação supranacional que faça com que a jurisprudência seja unificada e estabeleça uma norma vinculante, que pacifique e uniformize o ordenamento jurídico.

Para analisar as controvérsias surgidas nos Estados formadores do Mercosul, estabeleceram-se outras formas de solução, como o Tribunal Arbitral ad hoc, composto por três árbitros para presidir os trabalhos, analisando a questão que for suscitada pelas partes conflitantes.

A possibilidade de se forçar o cumprimento do laudo arbitral, por intermédio de medidas drásticas, como a suspensão de concessões; a imposição de tarifas aduaneiras especiais; e a criação de barreiras não tarifárias, são situações que descaracterizam a finalidade do bloco. O que se busca é a formação de um mercado comum, uno e, acima de tudo, integrado. Ao fazer uso de instrumentos econômicos para impor o cumprimento de uma decisão, viola-se o princípio da igualdade, uma vez que é notória a disparidade entre os países constituintes do bloco.

A integração mercosulina, embora marcada por dificuldades de ordem econômica, surge com o intuito de concretizar a formação de um mercado comum. Mesmo apresentando-se de forma diversa da comunidade européia, almeja alcançar a 
mesma projeção, constituindo, dessa forma, um nível superior de integração entre os Estados-membros.

O objetivo principal do Tratado de Assunção era atingir o Mercado Comum até o ano de 1994, oportunidade na qual seriam implementados os órgãos definitivos previstos no art. $9^{\circ}$, inclusive com a instituição de um sistema permanente de conflitos. Diante da frustração dessa meta, firmou-se o Protocolo de Ouro Preto, no ano de 1994. Infelizmente, este protocolo manteve a postura conservadora, circunstância que afastou ainda mais o objetivo da supranacionalidade do bloco.

O novo sistema perpetuou a idéia de que todas as decisões deliberadas devem ser tomadas através do consenso.

"Vê-se que, em sua essência, o Mercosul objetiva a comunitariedade. Como bem observado por SEITENFUS (2006, p.220), “o Mercosul aproxima-se de uma ordem comunitária na medida em que possui fontes autônomas em relação às ordens nacionais". Percebe-se tal intuito através dos mecanismos que são tidos como fontes visto que são elaboradas por órgãos da estrutura intergovernamental do bloco:

\footnotetext{
Artigo 41 - As fontes jurídicas do Mercosul são:

I. O Tratado de Assunção, seus protocolos e os instrumentos adicionais ou complementares;

II. Os acordos celebrados no âmbito do Tratado de Assunção e seus protocolos;

III. As Decisões do Conselho do Mercado Comum, as Resoluções do Grupo Mercado Comum e as Diretrizes da Comissão de Comércio do Mercosul, adotadas desde a entrada em vigor do Tratado de Assunção.
}

Percebe-se, pois, que o novo sistema apresentado pelo Protocolo de Ouro Preto mostrou-se ineficaz, ou melhor, não conseguiu atingir os objetivos da supranacionalidade e da integração. $\mathrm{Na}$ verdade, o argumento utilizado para a perpetuação das idéias iniciais do Mercosul foi a existência de grande disparidade econômica entre os países.

O Protocolo de Ouro Preto apenas deixou dúvidas acerca de sua real intenção de busca pela interação. Se por um lado, trouxe certos avanços no que tange à integração mercosulina, por outro, contribuiu para a permanência de uma imensa lacuna no sistema de solução de controvérsias. Face essa situação, em 18 de fevereiro de 2002 foi adotado o Protocolo de Olivos para a solução das possíveis controvérsias. 
O Protocolo de Olivos, entretanto, ficou bem longe de promover uma alteração substancial no sistema de solução de controvérsias. Muito embora tenha instituído mudanças fundamentais no que diz respeito à solução de litígios, sobreleva notar que as inovações são insuficientes para se alcançar a almejada supranacionalidade.

Instituiu o protocolo supra mencionado que a lei aplicada na solução de desídias é o Direito Mercosulino, integrado pelas seguintes normas: Tratado de Assunção, Protocolo de Ouro Preto, protocolos e acordos celebrados no marco do Tratado de Assunção, decisões do Conselho do Mercado Comum (CMC), resoluções do Grupo Mercado Comum (GMC) e diretrizes da Comissão de Comércio do Mercosul $(\mathrm{CCM})^{10}$.

Outrossim, o Protocolo de Olivos determina a aplicação do Direito Internacional Público e de sua principiologia. Pelo exposto, percebe-se que o "direito mercosulino" está vigendo. Diante disso, faz-se necessária sua incorporação nos ordenamentos jurídicos dos países-membros.

Ressalva Ramón Lisboa (2006, p.102):

\begin{abstract}
Portanto, embora de forma lenta e titubeante, o projeto mercosulino progride na formação das suas instituições jurisdicionais, arrastando o peso da intergovernamentalidade, e com isso comprometendo a criação do almejado mercado comum, nada obstante tenha sido essa característica que permitiu a existência do bloco durante as piores crises.

Ainda assim, mesmo diante de estruturas minimalistas e deficitárias, os Estados voltam-se para a idéia de um Espaço de Justiça Transfronteira, elaborando instrumentos que facilitam a cooperação jurisdicional para cumprimento de sentenças proferidas intrabloco.
\end{abstract}

Assim, destaca-se que o projeto de formação de um Mercado Comum no âmbito do Mercosul apresenta deficiências que impedem a instituição de uma organização supranacional.

\title{
3. A POSSIBILIDADE DE IMPLEMENTAÇÃO DO MECANISMO DE COOPERAÇÃO JURISDICIONAL TRANSFRONTEIRIÇA: UMA ANÁLISE COMPARATIVA ENTRE O MERCOSUL E UNIÃO EUROPÉIA
}

\footnotetext{
${ }^{10}$ Ainda, cumpre referir que os limites do objeto da controvérsia devem ser traçados quando da apresentação, diante do Tribunal Arbitral, da reclamação e da resposta, sendo que, fora das matérias declinadas nesses documentos, não será lícito pronunciamento, sob pena de incorrer em julgamento extrapetita (art. 14).
} 


\subsection{Aspectos determinantes do caráter não-supranacional}

Pelo que já foi demonstrado, percebe-se que existe uma diferença significativa no que pertine à integração e à supranacionalidade no âmbito do Mercosul e da União Européia. Diversos fatores são geradores de tal condição. O objeto da análise que se fará a seguir é exatamente este: tornar claro que não há cooperação jurisdicional no Mercado Comum do Sul.

É notória a disparidade sócio-econômica presente entre os países formadores do Mercosul, uma vez que se sabe que nenhum deles está no grau de desenvolvimento existente nos Estados-membros da Comunidade Européia. Este é, sem sombra de dúvida, um dos fatores que impedem que a bloco mercosulino atinja o grau de integracionalidade que é encontrado na União Européia.

Outro aspecto importante é o fato de que no Mercosul inexiste um Tribunal permanente que garanta a supremacia do direito comunitário em detrimento do direito comum. Há, apenas, um Tribunal arbitral “ad hoc”, cujos árbitros são eleitos pelos próprios Estados envolvidos na controvérsia para cada questão suscitada, circunstância essa que gera uma disparidade jurisprudencial, ocasionando uma ausência de uniformidade na interpretação das normas mercosulinas pelos juízes nacionais. Ademais, as normas emanadas desses órgãos institucionais não estão sujeitas a um controle de legalidade, circunstância que, por si só, gera uma incompatibilidade como sistema de integração.

Sobreleva ressalvar que o princípio do consenso é outro fator impeditivo que impossibilita a cooperação jurisdicional transfronteiriça no Mercosul. Percebe-se que é necessário o consenso dos litigantes para a submissão do conflito ao Grupo Mercado Comum (GMC). Disso, conclui-se que - ao contrário do que ocorre na União Européia, onde qualquer dos litigantes pode suscitar o reenvio prejudicial - há dificuldade de subordinação dos países em razão da idéia ainda constante de soberania. O caráter nãosupranacional leva à impossibilidade de se falar em cooperação.

Desde seu lançamento, o Mercosul procurou implementar práticas que simplificassem o mecanismo de cooperação interjurisdicional, criando inclusive condições para melhor circulação dos pedidos probatórios, sentenças e medidas de caráter executivo, criando assim um Espaço Transnacional de Justiça (RAMON, 2006, p.103). 
Outra circunstância que pode levar à falsa idéia de que o Mercosul é um bloco supranacional são as chamadas Convenções Interamericanas de Direito Internacional Privado (CIDIPs). Por meio delas, promove-se um processo de harmonização e de uniformização do direito para os países das Américas. Outrossim, muito embora visem a constituição de um sistema uno e a elaboração de normas de direito comunitário aplicáveis ao bloco como um todo, facilitando, pois, a cooperação jurisdicional entre as nações, tem-se que as CIDIPs são insuficientes para alcançar tal objetivo. Ressalve-se que, embora assinadas pelos quatro países integrantes da Comunidade Mercosulina, não têm a mesma eficácia valorativa nos territórios, dependendo de procedimento interno de ratificação. Essa circunstância é outro obstáculo que impede a efetividade plena das mencionadas Convenções.

Percebe-se, ainda, que os países-membros do bloco também oferecem certa resistência à adoção de um sistema supranacional vinculante, impondo procedimentos divergentes acerca das regras mercosulinas, o que pode ser observado na análise jurisprudencial.

\subsection{A posição dos países frente às regras de Cooperação Jurisdicional do Mercosul}

O Brasil, desde a adesão ao Mercosul, apresentou-se cauteloso e receoso, demonstrando uma barreira intransponível (Ramón, 2006) fator esse que impede a comunitarização do direito, sob o prisma do princípio do consenso. O procedimento para a incorporação das normas mercosulinas está sujeita à apreciação do Superior Tribunal de Justiça (STJ), conforme a modificação implementada pela Emenda Constitucional n. ${ }^{\circ} 45 / 04$. Pela reforma constitucional, o Brasil, ao invés de partilhar a competência entre os juízes nacionais, consubstanciando a cooperação direta, apenas transmutou a competência do Supremo Tribunal Federal (STF) para o STJ.

Interessante é o exemplo de grande repercussão que Ramón Lisboa citou em sua tese (2006, p.122) no qual o juiz da Comarca de Santana do Livramento pretendeu dar cumprimento à medida cautelar através de carta rogatória enviada pela Justiça da cidade de Rivera. A Corte Suprema do Brasil cassou a decisão, sob o fundamento de que o ato estaria na esfera de competência originária do STF (atualmente deslocada competência para o STJ, permanecendo, contudo, seu caráter concentrado), a quem 
incumbia com exclusividade homologar sentenças estrangeiras e conceder exequatur às cartas rogatórias emanadas de autoridades judiciárias de outros países ${ }^{11}$.

Alguns outros exemplos podem ser apontados para demonstrar ineficácia da Cooperação Jurisdicional Transfronteiriça no âmbito do Mercosul $^{12}$, sendo que em todos se observa a dificuldade de implementação do sistema.

No Uruguai, percebe-se uma posição diferente. A adoção de políticas de cooperação internacional é vasta, circunstância que enfatiza o objetivo de formação de um espaço transfronteiriço da Justiça. É notória a flexibilidade do país no sentido de formar um bloco supranacional. Pode-se exemplificar tal circunstância com o reconhecimento de sentença estrangeira: para que uma sentença tenha plena validade e eficácia, basta que preencha os requisitos clássicos trazidos pela PCAJ (Protocolo de Cooperação e Assistência Jurisdicional em Matéria Civil, Comercial, Trabalhista e Administrativa), estabelecido pelo Mercosul. Seria muito mais simples se todos os países o adotassem, pois assim se aumentaria a cooperação jurisdicional transfronteiriça no âmbito do bloco.

A presença de uma legislação que privilegia o processo de integração caracteriza também o Paraguai. A própria Constituição, datada de 07 de fevereiro de 1831 e, portanto, anterior à criação do Mercosul, prevê que o país promoverá a solidariedade e a cooperação internacional. Observa-se, de plano, a intenção do

\footnotetext{
${ }^{11}$ STF Recl. 717: competência exclusiva do STF (Mercosul) DESPACHO: Trata-se de reclamação formulada contra ato do Juiz de Direito da Comarca de Santana do Livramento/RS, que, havendo alegadamente concedido exequatur a carta rogatória que lhe foi encaminhada diretamente por magistrado estrangeiro (Juiz de Rivera, Uruguai), teria usurpado a competência monocrática do Presidente do Supremo Tribunal Federal, em cujas atribuições se inclui o poder de determinar a execução, em território brasileiro, de providências constantes de comissões rogatórias dirigidas ao Poder Judiciário do Brasil. Consta que o magistrado estadual gaúcho teria invocado, como fundamento jurídico supostamente autorizador de sua decisão, o Protocolo de Las Leñas. O ora reclamente - considerada a situação de urgência que alega - formula pedido de imediata suspensão cautelar de eficácia do ato ora impugnado, cuja prática foi determinada pelo Juiz de Direito da Comarca de Santana do Livramento/RS (Direção do Foro). Disponível em : <http://www.stf.gov.br>

${ }^{12}$ Em 13 de janeiro de 1998 a Juíza de Direito da Fazenda Pública do Rio Grande do Sul, Liselana Schiffino Robles Ribeiro ditou a sentença no caso Leben contra a administração Tributária do Estado do Rio Grande do Sul na que deu preeminência ao Tratado de Assunção que estabeleceu o Mercosul sobre o direito interno brasileiro. No caso, se tratava da importação de leite embalado pronto para o consumo, similar ao produto nacional brasileiro proveniente do Uruguai. O Estado do Rio Grande do Sul aplicava um imposto à circulação de mercadorias e serviços ao leite uruguaio que não se aplicava ao similar nacional. O importador do leite uruguaio solicitou a Justiça um tratamento similar ao dispensado ao produto nacional, ao qual no era cobrado tal imposto. A respeito do artigo 7 do Tratado de Assunção dispõe: "Em matéria de impostos, taxas e outros gravames internos, os produtos originários do território de um Estado Parte gozarão, nos outros Estados, taxas e outros encargos internos, os produtos originários Partes, do mesmo tratamento que se aplique ao produto nacional". A Juíza deu lugar ao pedido da empresa importadora sinalizando: "Conforme já decidiu o Supremo Tribunal Federal, para que a legislação interna possa dispor em sentido contrário ao disposto nele se contenha, exige-se sua prévia denúncia, pois o tratado contratual é título de direito subjetivo". Citou também o artigo 152 da Constituição do Brasil: "É vedado aos Estados, ao Distrito Federal e aos Municípios estabelecer diferença tributária entre bens e serviços, de qualquer natureza, em razão de sua procedência ou destino". "Portanto"-Conclui a Juíza- "sendo o leite embalado, pronto para o consumo produzido no Brasil beneficiado por uma isenção tributária, também o é um produto similar estrangeiro". A ordem jurídica do Mercosul, como toda ordem jurídica, deve estar dotado de órgãos e procedimentos para criar as normas, interpretá-las e assegurar seu cumprimento. As normas são criadas pelo Conselho, o Grupo Mercado Comum e a Comissão de Comércio. O Protocolo de Brasília para a solução de controvérsias, por sua vez, prevê a constituição de tribunais arbitrais para todos os caso de interpretação, aplicação ao incumprimento das normas do Mercosul. Disponível em <http://www.embarg.org.br/ArtJhv1.htm >
} 
legislador paraguaio em implementar, da maneira mais objetiva e eficaz, o espaço supranacional cooperado, possibilitando, portanto, a efetividade da jurisprudência alienígena.

No que pertine à Argentina, não se observa violações aos protocolos instituidores do Mercosul. $\mathrm{O}$ ordenamento jurídico argentino não segue os padrões dos países integrantes da comunidade mercosulina. Na realidade, falta-lhe uma unicidade centralizadora (Ramón, 2006) que seja capaz de promover a integralização e a sistematização das normas. Assim, inexistindo um sistema unificador de normas, circunstância essencial para a cooperação jurisdicional, percebe-se que a implementação de um sistema transfronteiriço resta prejudicada.

\subsection{O confronto Mercosul e União Européia}

O Mercosul e a União Européia são formações discrepantes, que divergem em vários aspectos e possuem níveis de alcance das suas atividades também diferenciados. De tal maneira, pode-se fazer um paralelo entre estes blocos e perceber em que situação se encontra cada processo de integração. É exatamente essa diferenciação que se pretende mostrar a partir de agora, ao reproduzir, primeiramente, o modelo do Mercosul e, por conseguinte, o mais moderno, mas nem por isso infalível, modelo da União Européia.

Como já relatado, com o Tratado de Assunção e, posteriormente, com o Protocolo de Ouro Preto, foram instituídas regras a serem seguidas e respeitadas pelos Estados formadores do bloco mercosulino. Porém, em nenhum desses acordos foi estabelecido a criação de um órgão supranacional, como ocorre na União Européia, com o Tribunal de Justiça. No Mercosul, cada Estado-membro possui interesses próprios, ou seja, a vontade predominante é a estatal, não havendo o pensamento do interesse comunitário. A intergovernabilidade é predominante e as normas jurídicas internacionais, para terem efeitos internamente, devem passar por um processo de internalização, ou seja, não há primazia das regras internacionais frente aos ordenamentos nacionais.

Quando a estrutura institucional é baseada no processo de intergovernabilidade, cada Estado-membro preserva sua autonomia ao extremo e, conseqüentemente, não altera suas decisões nem sua posição anterior ao início do processo de integração. Prevalecem as vontades individuais, buscando-se apenas a harmonização entre elas. 
Já o mesmo não se pode falar quanto ao modelo europeu. Na Comunidade Européia o interesse primordial é o comunitário, no qual o coletivo se sobrepõe ao individual e até mesmo aos dos Estados-membros. Essa primordialidade é reconhecida como o poder de supranacionalidade, podendo ser representada pela superioridade das normas jurídicas, prevalecendo o que os órgãos autônomos ditaram como regras, com aplicação imediata e superiores às internas de cada Estado.

Segundo Pierre Pescatore, citado por Jânia Lopes Saldanha, a supranacionalidade estará presente quando reunir três elementos: I) presença de interesses comuns entre os Estados; II) institucionalização colocada a serviço de interesses comuns e III) autonomia destes poderes em relação aos Estados-membros ${ }^{13}$.

Assim, resta demonstrada a superioridade da Comunidade Européia quanto a sua organização e poder de soberania compartilhada que tem rendido belos frutos ao bloco modelo. Em função disso, boa parte da doutrina mostra-se favorável a alteração do modelo de intergovernabilidade do Mercosul pelo de supranacionalidade, adquirindo, por certo, forças renovadas e um modelo de solução de conflitos mais apurado, já que, por via de conseqüência, seria interessante dar-se um passo ainda maior e implantar um Tribunal supranacional. Este órgão seria o mais adequado para resolver os impasses que surgem nos Estados e que necessitam de uma solução rápida e vinculante aos juízes nacionais, podendo então ocorrer a tão sonhada harmonização da jurisprudência entre os países formadores do bloco. E é exatamente neste ponto que surge o questionamento: poderá existir um Tribunal de Justiça sem a adoção da supranacionalidade?

Será possível instituir o mecanismo da Cooperação Jurisdicional em um bloco com uma estrutura ainda precária e carente de políticas comunitárias e integracionistas? Pelos diversos motivos já expostos, acredita-se que não.

\section{CONSIDERAÇÕES FINAIS}

O intuito deste trabalho é relatar o paradigma jurisdicional existente na União Européia contrastando-o com o singelo modelo mercosulino, como restou evidenciado durante todos os tópicos abordados.

\footnotetext{
${ }^{13}$ Ob cit., p.111.
}

ISSN 1981-3694

C 2008. Departamento de Direito da UFSM. Todos os direitos reservados. 
A estrutura do Mercosul possui uma clara deficiência na área destinada à solução de conflitos judiciais, ou seja, ainda há provisoriedade no sistema de solução de controvérsias e os laudos arbitrais não são totalmente confiáveis, já que a supranacionalidade não se faz presente neste aglomerado de países latino-americanos. Assim, a Cooperação Judicial Transfronteiriça faz-se tão carente quanto a sustentabilidade do próprio bloco econômico.

Diante do exposto, não se torna fácil para o Mercosul a implementação de um órgão supranacional vinculante, que estabeleça de forma direta e objetiva a harmonização jurisprudencial dos países pertencentes à comunidade mercosulina. Nem tampouco é viável a aproximação dos juízes nacionais para facilitar a estrutura do reenvio judicial, posto que, pelo menos no Brasil, não há norma constitucional permitindo a solução dos conflitos por uma Corte única.

Como dito durante o decorrer do trabalho, para isso acontecer seria necessário que cada Estado-membro doasse parcela de sua soberania (soberania compartilhada) em prol da internacionalização das regras internacionais. Todavia, percebe-se como o pensamento individualista está sobrepondo-se ao coletivo e dificultando a adoção de mecanismos capazes de favorecer os juízes nacionais na interpretação e validade das normas comunitárias.

É visível que para o desenvolvimento do Mercosul, em comparação com a União Européia, a adoção da supranacionalidade e, como consequiência, também do Tribunal de Justiça, são indispensáveis e servirão de base para o progresso do instituto do reenvio prejudicial, "amigo inseparável” do juiz nacional. Com todos os mecanismos em pleno desenvolvimento, poder-se-á colocar em prática a tão sonhada cooperação jurisdicional transfronteiriça, transformando o Mercosul em um bloco de relevância tamanha tal qual a União Européia.

Para o sucesso do empreendimento, dependeria da vontade dos países integrantes em firmarem um tratado internacional para instituir um órgão que permitisse essa uniformização na aplicação das leis mercosulinas e viabilizasse a cooperação judicial transfronteiriça para com os quatro países formadores do bloco do Mercosul e mais seus associados.

Só que essa utopia, por assim dizer, pode demorar muito a tornar-se realidade, já que o modelo mercosulino distancia-se muito do europeu. Justamente por haver tantas disparidades entre os dois blocos é que não se concebe a idéia de exigir-se tão ISSN 1981-3694

(C) 2008. Departamento de Direito da UFSM. Todos os direitos reservados. 
rapidamente uma simetria entre suas estruturas jurisdicionais de cooperação. Não há modelos perfeitos, isentos de falhas a serem "copiados", apenas alguns promissores como o modelo Europeu, por isso não podemos afastar a idéia do Mercosul unir suas forças e implantar também uma Justiça una.

\section{REFERÊNCIAS BIBLIOGRÁFICAS}

LISBOA, Ramon. Justiça Transfronteiriça: uma análise comparativa das estruturas judiciais e mecanismos de cooperação jurisdicional em matéria civil e comercial entre o Mercosul e a União Européia \{Tese\}. Santa Maria: MILA, 2006.

POZZATTI JR., Ademar. Mecanismos de Cooperação Jurisdicional e de Harmonização da Aplicação do Direito Regional: assimetrias entre o Mercosul e a União Européia. \{Monografia\}. Santa Maria: 2007.

SALDANHA, Jânia Maria Lopes. Cooperação jurisdicional. Reenvio Prejudicial: um mecanismo de direito processual a serviço do direito comunitário: perspectivas para a sua adoção no Mercosul. Porto Alegre: Livraria do Advogado, 2001.

SEITENFUS, Ricardo [Org.]. Legislação Internacional. São Paulo: Editora Manole, 2004 .

SEITENFUS, Ricardo; VENTURA, Deisy. Direito Internacional Público. Porto Alegre: Editora Livraria do Advogado, 2006.

http://www.mercosur.org.uy

http://europa.eu/index_pt

http://www.stf.gov.br

http://www.stj.org.br

http://www.embarg.org.br/ArtJhv1.htm

ISSN 1981-3694

(C) 2008. Departamento de Direito da UFSM. Todos os direitos reservados. 
http://www.direito.unisinos.br/ caliendo/arquivos/Jurisprudencia.doc 